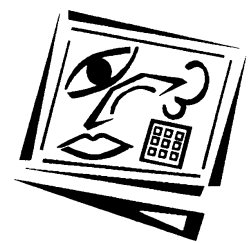

\title{
Breaking down online teaching: Innovation and resistance
}

\author{
John Hannon \\ La Trobe University
}

\author{
An Outstanding Paper Award recipient, ascilite Melbourne 2008 Conference
}

\begin{abstract}
The term "innovation" is associated mainly with change in practice using educational technology. This paper explores the question of why innovations in online teaching and learning in higher education break down or deliver less than they promise: why they are so resource intensive, so prone to breakdown, and why they often fail to live up to their promises? Two cases of innovation were selected from a broad doctoral research project across three Australian universities, involving 24 interviewees. One case was a bottom up, wiki based learning space inspired by a constructivist commitment, the other a top down response to organisational change in a degree program. Despite literature on case studies which offer useful, evidence based approaches and models for online pedagogy, there is a lack of analytical perspectives with which to engage with breakdowns and "thwarted innovation" in online learning. The focus in this paper is online teaching, and breakdowns are scoped beyond the technologies involved and encompass social, material and discursive entities. An actor network perspective (Callon 1986; Latour 1987; Law 2000) is used to explore the relationality between social and technological entities, and the sociotechnical assemblage which constitutes online teaching. It argues that (i) crucial factors are hidden by the normative perspective inherent in the implementation of technology systems, and (ii) recognising the connections between the social, material and discursive entities in online learning offers a strong analytic basis for innovative teaching and learning practice.
\end{abstract}

\section{Introduction}

Innovation in higher education has been variously associated with learning technologies, pedagogical approaches, organisational processes, grant opportunities (Alexander, 2006), responses to globalisation, and the agendas of government (Roberts, 2004). The term is put to many uses, from government policy, to frequent appearances in university vision statements, and as a rhetorical participant in organisational change. Despite its fuzziness and questions about the meaning of the "new" inherent in the term (Conole, de Laat, Dillon \& Darby, 2008; Alexander, 2006), the connecting theme of innovation in higher education contexts seems to be significant change, and its potential to transform practice. As an example, the appropriation by learners of social software technologies of interaction and collaboration is identified as a "disruptive" type of innovation such that "we are reaching a turning point in the way technology is used for learning" (Conole et al. 2008, p. 511). Others agree that user centred and Web 2.0 technologies represent an innovative shift for online learning (McLoughlin \& Lee, 2008; Downes, 2006; Oblinger \& Oblinger, 2005). 
Conole et al. (2008) also point out that the rhetoric that accompanies e-learning at the policy level probably does not match changes in practice (p. 511). In considering the history of online learning in higher education that is associated with innovation as organisational change, the record indicates a pattern of immense investment, "thwarted innovation" (Zemsky \& Massy, 2004), recurring breakdowns, costly failures and unintended outcomes (Bacsich, 2005; Conole, 2007; Cornford \& Pollock, 2003, p. 85; McMullin, 2005; Warzynski, 2006). Reasons that emerge from studies of online learning are: approaches to change and technology implementation are too narrowly focussed (Warzynski, 2006), or limited by an "information view of higher education" (Cornford \& Pollock, 2003, p. 41); there is a disparity between how different groups understand key organisational terms, which may be taken up in different ways in the organisation (Lewis, Marginson, \& Snyder, 2005); there is a mismatch of goals between organisational participants in a project, such as a technological, organisational or pedagogical focus (Cornford \& Pollock, 2003, p. 85; Weisenberg \& Stacey, 2005, p. 401); a technology centred approach and a lack of integration of all elements of an innovation (Goodyear \& Ellis, 2008; Romiszowski, 2004), and too much focus on the "how" of technology use, rather than the what and who involved (Bigum \& Rowan, 2004, p. 218).

Online learning innovation seems to mirror the track record of information technology projects in the business and government sectors, where there is evidence that failure has a "long, dismal history" (Charette, 2005), and breakdowns or unexpected outcomes have arguably become a normal part of the experience of working with large technological innovations. Such unhappy outcomes suggest that the project of integrating online learning technologies into organisations is narrowly understood.

This paper explores the question of why innovations in online teaching and learning in higher education break down or deliver less than they promise. While this is intentionally a negative starting point, my aim is to offer a less narrow analytical perspective to bring to the high incidence of breakdowns in online teaching and learning. Breakdowns, then, may be scoped beyond the technology involved, and encompass other contributing interests in a project: any social, material or discursive participant. My focus in this study is on online teaching, since that is the intersection of all the participants in such ventures - the technologies, the organisations, the knowledge, the teaching staff, and students - all those who together make it work, or not.

Bigum and Rowan (2004, p. 214) contrast two approaches to the deployment of technologies into teaching and learning: the "corporate approaches", which tend to be implementations of proprietorial software across the whole organisation, and "maverick approaches" to flexible and online learning, usually individualised, small scale undertakings.

Two case studies of innovations in online teaching were selected from one Australian university, which reflected the two expressions of innovation indicated by Bigum \& Rowan above: an individual, localised, innovation in online pedagogy using wiki technology; and an organisational innovation to provide mass learning enabled by online technology. These two cases were in fact successful in narrow technical terms, but breakdowns in practice occurred. My contention is that the separation of social and technological entities in online teaching, such that either one is assumed or considered fixed, will produce breakdowns in practice. A relational perspective incorporating all 
the entities participating in online teaching - material, discursive, and social - offers a fresh alternative perspective on innovation to orthodox implementations informed by technology units or organisational structures (Alvesson \& Sveningsson, 2008; Cornford \& Pollock, 2003).

\section{A relational perspective on technology and practice}

The technologies of everyday work, such as a filing cabinet, email or an institutional learning management system (LMS), tend to be encountered as a bundled set of functions and uses, mainly fixed, and little remains to be negotiated. They are then absorbed as a "tool" into the practice of day to day work. A discourse in which technologies are tools, and inherently neutral, itself acts on the setting of use and may implicate the humans participants. Any issues or problems associated with their use are resolved after according a status of neutrality to the object: perhaps it is the wrong tool for the purpose required, or the user needs training on its proper use.

Don Ihde posits the non-neutrality, and "non-innocence", of technologies that perform an action which may have transformative effects, for which he implicates the nonhumans (Ihde, 2002, p. 94). An alternative way to think of technologies is that they embody a condensed set of relations: they represent the end of a process of design and development involving many participants in which selections and decisions are made, until finally this chain of relations is stabilised into a material or digital form. John Law emphasises the contingency of these relations that make up an object, which "is an object as long as everything stays in place" (Law, 1999a). Technologies, texts, discourses and notions of pedagogy do not exist by themselves, rather they are assembled from and act in local settings. Hence such a object "is an effect of its relation to other entities" (Law, 2000).

In this study I bring a relational perspective to the way people work with innovations in their academic practice of online teaching. This perspective derives from two theoretical directions which converge in this analysis: actor network theory (Callon, 1986; Latour, 1987; Law, 1999b) is used to explore relations between actors - both human and nonhuman - in situated cases of breakdown in online teaching and learning. In addition, a discourse analytic approach was used to connect those local actors to broad patterns of discourse associated with online teaching in higher education, based on a method called "interpretative repertoires" developed by Potter and Wetherell (1987), which is concerned with the "action orientation" of discourse (see Hannon, 2008). Discourses emerging from pedagogical theory, from institutional policies, and from disciplinary practices, are able to be transported across contexts as "tokens of text or talk" (Cooren, Matte, Taylor, \& Vasquez, 2007, p. 155), that is, they are able to travel as relatively fixed textual entities from one point to another, and take effect on local contexts. They become, in actor network terms, "immutable mobiles" (Latour, 1987). Discourses, then, become globalised, "Looking across policy texts from around the world, it appears that descriptions within policy discourse are relatively stable, they emerge again and again in quite similar formulations" (Edwards, Nicoll, Solomon, \& Usher, 2004, p. 151). These authors give the example of "flexibility" and "lifelong learning" as two such globalised discourses. Discourses associated with teaching and learning in higher education, therefore, become actors in local settings: they offer descriptions which have an "action-orientation", that is, they can be "used to accomplish an action, and it can be analysed to see how it is constructed so as to accomplish that action" (Potter, 2000, p. 108). The method of interpretative repertoires 
and the concept of immutable mobiles can be used to bridge analysis of local, situated discourses with Foucauldian discourse analysis of institutional effects of power relations (Cooren et al., 2007, p. 154). In this study, interview accounts were analysed to account for the shaping of notions and practices in situated contexts by broader preexisting discourses and rhetorical strategies.

Using the relational perspective, I will attempt to analyse what constitutes an innovation in practice, and how it persists or breaks down. In Law's "radical relationality" (2000), there are no fixed or static categories, and connection is emphasised rather than the object or person, "elements have no significance except in relation to their neighbours, or the structure of the system as a whole". A core principle of the relational approach is heterogeneity: the symmetry of the human and non-human, such that one is not privileged nor takes agency over the other in any analysis. Hence what is important is the extent of strong and weak ties that make up the network, or the sociotechnical assemblage (Latour, 1986), which "hybridizes the social and the technical" (Arnold, 2007). The term "assemblage" more accurately describes the sense of "network" in actor network theory that predates the Internet (Latour, 1999a, p. 15), and in doing so conveys the sense of contingency and fragility of the connections that comprise the set of relations under analysis. Latour (1999b) offers the example of a speed bump, which "is ultimately not made of matter; it is full of engineers and chancellors and lawmakers, commingling their wills and their storylines with those of gravel, concrete, paint, and standard calculations." (p. 190). The entities that need to be brought into the assemblage may be uncooperative and offer resistance, and Bigum \& Rowan (2004) refer to the "unruliness" of the assemblage of entities that make up teaching (p. 220). For example, the assemblage that constitutes "learning" in higher education is described by Edwards et al. (2004):

Learning involves the enrolment and mobilization of heterogeneous elements: for example supervisors, colleagues, peers, laboratories, test-tubes, computers, the configuration of space, journal articles, conferences, funders and many more. All these and the relationships between them forges the network that needs continual management (p. 90).

From this perspective, we can uncover the "hard work" involved in assembling and maintaining "heterogeneous bits and pieces" (Law, 1992) into a stabilised or "blackboxed" assemblage. Latour refers to "blackboxing" as the way "technical work is made invisible by its own success" (1999b, p. 304). A black box is a set of relations, a hybrid of social and material elements, that constitutes the temporary settling of a controversy (Callon, 1986), that persists and is transportable. By implication, there is resistance and work still required in assembling and maintaining such a network of relations. This work of relating or associating elements is translation (Callon 1986), in which participants are engaged, aligned and assembled, and project goals are achieved when the assemblage of heterogeneous elements has been enrolled and mobilised. Fox (2005) described translation of people into professionals:

People are enrolled by teachers and translated into "learners"; they form queues to buy books, get in line to join the ranks of the professions, become this or that professional identity ... (Fox, 2005, p. 106)

In translation, one element can stand in for others, which then become blackboxed, or assumed, or presumed. In an online teaching context, an institutional implementation of an LMS is a black box in which many decisions about procedures (and perhaps practice) are embodied in irreversible technological choices: it is a hybrid that is a 
stabilisation of institutional and pedagogical controversies into a sociotechnical assemblage. This stable assemblage becomes transported when a discourse is organised, reified and mobilised into a powerful rhetorical black box to become an immutable mobile, for example, "student centred learning", "LMS" or "Workchoices".

Innovation occurs within a context of change, or to use Callon's (1986) term, a "controversy". Callon (1986) and Latour (1987) identify four not necessarily consecutive "moments" of translation in analysing a controversy. These can be outlined:

1. Problematisation or "how to become indispensable" (Callon, 1986, p. 203), in which key stakeholders or assemblages are defined. Key actors will attempt to establish themselves as an "obligatory passage point" around a problem (p. 206). For examples, teachers are an obligatory passage point around education.

2. Interessement: engagement of key actors and translation of their interests into the assemblage.

3. Enrolment: coordination of actors as translators, delegation of roles around project.

4. Mobilisation: alignment of the assemblage and strategies for expansion, where actors, large, small, concrete or abstract, come to be mobilised as actors. One stands for many.

The assemblage achieves mobilisation as a black box, when "all previous discussion, questions, assumptions and, maybe, controversy are closed down and are no longer visible as the technology moves from a private to a public domain" (Cornford \& Pollock, 2003, p. 19).

These moments can be represented, using the example of the translation of a student into a professional from Fox (2005) above, in Table 1:

Table 1: Actor network "moments"

\begin{tabular}{|l|l|l|l|}
\hline $\begin{array}{l}\text { Problematisation } \\
\text { Define problem or } \\
\text { controversy. }\end{array}$ & $\begin{array}{l}\text { Interessement } \\
\text { Engagement of key } \\
\text { actors, their goals } \\
\text { diverted or changed. }\end{array}$ & $\begin{array}{l}\text { Enrolment } \\
\text { Alignment of goals, } \\
\text { values, displacement. }\end{array}$ & $\begin{array}{l}\text { Mobilisation } \\
\text { Network alignment } \\
\text { and expansion. One } \\
\text { element stands for } \\
\text { many and acts. } \\
\text { Blackboxing. }\end{array}$ \\
\hline $\begin{array}{l}\text { Individuals aim to join } \\
\text { the law profession. }\end{array}$ & $\begin{array}{l}\text { Are engaged into } \\
\text { subjects, classes, } \\
\text { timetables. }\end{array}$ & $\begin{array}{l}\text { Are translated into } \\
\text { learners. Progression, } \\
\text { assessment, award. }\end{array}$ & $\begin{array}{l}\text { Enter and act in the } \\
\text { profession. The lawyer } \\
\text { becomes a black box. }\end{array}$ \\
\hline
\end{tabular}

\section{Action at a distance}

While the actor network approach is deployed specifically to focus on relational materiality arising from a local setting, its analytical scope need not be limited by the situatedness of its actors, as suggested by one critic (Couldry, 2008, p. 165). Opening the black box of online teaching exposes the discourses that connect those local actors to the possibility of "action at a distance" in which documents, papers and policies are "highly portable and retain their form and shape" (Cornford \& Pollock, 2003, p. 43) as they circulate and perform. Discourses, also, of pedagogy, technology and policy become relatively stable, and are mobilised through global dissemination of policy text (Edwards et al., 2004, p. 165). A discourse about online learning, then, can make use of "the shared assumptions and cultural memories that exist between authors and 
audience" (p. 19). Practice, however, is the point at which concepts, discourses and innovations become concrete and embodied, where abstractions hit the ground.

\section{Comparing analytical perspectives}

The analytical perspectives from a business process or "information view" (Cornford \& Pollock, 2003) is compared to the relational in Table 2.

Table 2: Analytical perspectives on innovation in online teaching

\begin{tabular}{|l|l|l|}
\hline \multicolumn{1}{|c|}{ Analysis } & \multicolumn{1}{|c|}{ "Information view" } & \multicolumn{1}{c|}{ Relational perspective } \\
\hline Innovation as & $\begin{array}{l}\text { Implementation - a business } \\
\text { process to be project managed }\end{array}$ & $\begin{array}{l}\text { Problematisation - a set of social and } \\
\text { technical relations to be negotiated }\end{array}$ \\
\hline $\begin{array}{l}\text { Learning } \\
\text { technology as }\end{array}$ & Tool or application for something & $\begin{array}{l}\text { Revealing or opening a space of } \\
\text { interaction }\end{array}$ \\
\hline Process & $\begin{array}{l}\text { Manage and allocate time, cost, } \\
\text { resources to achieve project goals }\end{array}$ & $\begin{array}{l}\text { Align "unruly" entities and overcome } \\
\text { resistances until a sociotechnical } \\
\text { assemblage is achieved }\end{array}$ \\
\hline Examples & $\begin{array}{l}\text { Implementation of an LMS, of an } \\
\text { institutional e-portfolio }\end{array}$ & $\begin{array}{l}\text { speed bump, "flexible learning", } \\
\text { an LMS, a wiki }\end{array}$ \\
\hline Assumptions & $\begin{array}{l}\text { Separation of humans, technology } \\
\text { and goals }\end{array}$ & $\begin{array}{l}\text { Symmetry of humans and nonhumans - } \\
\text { social, material and discursive relations } \\
\text { constitute an assemblage }\end{array}$ \\
\hline Analysis & $\begin{array}{l}\text { Project management evaluation - } \\
\text { discrete entities, clear project } \\
\text { boundaries }\end{array}$ & $\begin{array}{l}\text { Actor-network approach - trace } \\
\text { alignments in an assemblage. Breakdowns } \\
\text { occur where alignments are weak }\end{array}$ \\
\hline
\end{tabular}

In the following case studies, the assemblages that constitute online teaching practice become visible during breakdown. We shall look for the source of breakdown in the "precarious" relations (Law, 1992).

\section{Method}

An interview approach with practitioners was used to explore situated technological and pedagogical contexts of online teaching and learning. The two specific cases in this paper were selected from a broader set of case studies involving 24 interviewees working across three Australian universities. A heuristic enquiry method was used in the broader studies, since the focus was on the experiences of individuals who shared common ground with the researcher in their practice (Patton, 2002, p. 107). A purposeful sampling method was used (p. 234), in which participants were selected on the basis of their commitment to innovative online teaching.

The two cases in this paper are based on interview transcripts with three participants in each case, a total of six participants from one university, with associated technological and textual objects, such as samples of online course material, a School seminar paper, and relevant institutional documents.

\section{Why does a successful innovation in online teaching fail?}

We all agree on the road rules, but we don't have to all drive Holden Barinas. Jack

Jack's innovation was an informal, "maverick" approach to online teaching as a response to his perceived limitations of the institutional LMS. He researched and set up a collaborative, wiki based platform for his teaching and learning, using his own 
expertise in computer programming with Unix and PHP to install the wiki on servers next door to his office (these he had acquired from a community project grant and acquiring unwanted university computers). He and several colleagues placed a number of units of study on the wiki. Having set up and configured a dedicated wiki platform and successfully used it for online teaching over two semesters, including for a class of 510 students, Jack subsequently abandoned his innovation.

Applying the actor network approach brings a focus on the associations that constitute the wiki project. I will limit the case to the actors associated with one of Jack's units of study, an undergraduate unit of a degree program, Computers and Society (a pseudonym, CS). Based on participants' accounts and related documentation, the sociotechnical assemblage of the wiki can be described initially as encompassing the following actors, that is, "entities who do things" (Latour, 1992): the unit CS, the unit content, the assessment based on the wiki, Jack as unit coordinator and as lecturer, the installed and configured wiki, a team of 13 tutors, a class of 510 students, institutional governance (policies on assessment, unit design, evaluation), Faculty staff (Dean, Head of School, administration, colleagues), information technology (IT) support, the student name database, Jack's servers, and the Faculty workload model.

To describe the process of assembling the actors and their associations that constitute Jack's innovation to teaching online, Callon's "moments of translation" can be used. These are represented in Table 3.

Table 3: The wiki assemblage

\begin{tabular}{|l|l|l|l|}
\hline \multicolumn{1}{|c|}{ Problematisation } & \multicolumn{1}{c|}{ Interessement } & \multicolumn{1}{c|}{ Enrolment } & \multicolumn{1}{c|}{ Mobilisation } \\
\hline $\begin{array}{l}\text { Models of pedagogy in } \\
\text { the technology: The } \\
\text { existing LMS was } \\
\text { found to be limited, an } \\
\begin{array}{l}\text { open-source } \\
\text { collaborative online } \\
\text { space was sought. }\end{array}\end{array}$ & $\begin{array}{l}\text { linking to student } \\
\text { names, engaging } \\
\text { tutors and students } \\
\text { with wiki. Lack of } \\
\text { involvement from } \\
\text { Faculty management } \\
\text { and IT support. }\end{array}$ & $\begin{array}{l}\text { Learning is translated } \\
\text { into the wiki: activities } \\
\text { and assessments are } \\
\text { located in wiki. }\end{array}$ & $\begin{array}{l}\text { Wiki becomes the } \\
\text { unit's primary } \\
\text { learning and } \\
\text { assessment space. }\end{array}$ \\
\end{tabular}

Problematisation: Jack found a mismatch between the LMS and his conceptions of teaching online. He found the LMS "very constraining", "cumbersome", and based on a model in which "there are no surprises, no uncertainty". Jack described his innovation as founded in the application of social constructivist learning concepts to open source software and a "model of the virtual community". The decision to adopt open source collaborative technology, and his methodical selection of the wiki (from a survey of over 200 wiki engines), followed from these conceptions of learning. Jack described his model of teaching online using the wiki as one based on trust and transparency, compared to the LMS model which, he said, was based on managing risk, and "overly concerned about people doing the wrong thing".

Interessement: This process describes the engagement, recruitment, and continual regeneration of interest for key actors in the wiki assemblage, and the strength of the associations between them. Jack overcame infrastructure issues with his own expertise, installing the wiki on his own servers, linking to the student name database, and organising students' individual spaces on the wiki. Two key sets of human actors were the 510 students and 13 tutors, who formed strong ties with both Jack as the unit coordinator, and the wiki as a platform for teaching online. The strength of ties in the 
assemblage diminished with the distance of actors from everyday activity. Jack's self sufficiency meant his links to Faculty management and IT were tenuous, "no one's saying stop it. ... but no one's saying do it... it's a thing of being on the sideline but being harmless". Further weakening the link between his wiki and the institution was Jack's workload calculation, which excluded the work of maintaining the wiki and supporting students in this and future iterations of the unit.

Enrolment: The process of translation can be described as "enticing and engaging" (Callon 1986) actors in the assemblage, and the creation of a key role in the wiki, which acted as the "obligatory passage point" (p. 206). Jack translated the wiki into an online learning space for 13 tutors and 510 students that matched his conceptions of learning in which "the curriculum can be more flexible". This flexibility of the wiki was illustrated in assessment, which was translated into a "disruptive" form not possible using the closed system on the LMS:

I have gone away from the model of students handing things up. When students have finished their work, they just take the hands off the keyboard. Because their work is always here, and I can see them as they construct it (Jack).

The wiki made possible an approach to assessment in which student's project work was visible to peers. Jack defined assessment in the wiki as an open ended, visible and transparent task, a mode which he deployed as a means of self regulation, "it's reasonably hard for people to cheat, really. I mean, they can collaborate, and they can look at each other's work and be inspired". While this approach was contingent on each student's agreement, Jack successfully delegated this agreement to the philosophy of openness and collaborative inherent in the wiki - there were no closed spaces within the wiki.

Mobilisation: This stage indicates the extent of support leading to stabilisation and extension or mobilisation of a network, and resistance can be identified in the weak ties linking actors. For Jack, the increase of student numbers from a small class to 510 was not problematic in technical terms, "scale is not an issue", moreover the unit was eventually completed successfully for all these students. However, there were sources of resistance which brought Jack to reconsider the future of the wiki: one was the potential for poor student evaluations:

There is, I mean, a lot of room to innovate here and there is no one stopping me. But in our present climate though, I think, if you innovate, sometimes it might not go well. (Jack).

Jack cited an instance of a negative reaction and student evaluation. The prospect of future upcoming classes of over 500 students linked the innovative pedagogy of the wiki to a potent institutional actor "student evaluation". As class sizes increased, so did the diversity of students' responses and their orientation to learning. (Jenny, a tutor in the wiki, alluded to this concern when she described the "pick n mix" student, that is, a student who considered participation optional). Student evaluation was present in the assemblage in two forms: materially as a survey of student responses to the unit, and as a token of the discourse concerning performance and improvement, a mobile actor with its own "transportation effects" (Cooren et al, 2007, p. 567), which acted to link students with institutional policy, and make more tenuous the ties between the wiki and the institution. 
At a follow up interview with Jack after his class of 510 students completed the unit on the wiki, Jack reflected on his decision to abandon the open assessment strategy enabled by the wiki, and largely abandon the wiki as the primary mode of online teaching. Instead, he used it only to house content, and provide a common development space for tutors only, rather than students. Other factors Jack identified in his decision were a lack of shared interest and connection with management and many colleagues, and the increase in workload in order to maintain the wiki, not accounted for in the workload model. Prospective student evaluations were a real actor in the wiki assemblage, as a potential but not yet material entity, yet they formed a resistance strong enough to overcome the mobilisation of the assemblage and ultimately lead to the break down of the sociotechnical assemblage. The status of the wiki innovation after two iterations was indicated by Jack's comment that he was now "not experimenting", and "we are still driving Holden Barinas".

\section{How is teaching practice negotiated in a shift to technology based mass learning?}

Fran taught an undergraduate unit in a program in the Health Sciences Faculty, one of several programs at the university undergoing a shift to online large class teaching using the LMS, shaped by conditions of organisational change and an associated institutional commitment to flexibility. Fran coordinated a unit, Communication in Practice (CP, a pseudonym), in which there were about 700 students, about half attending face to face classes (internal), and half off campus (external), including a large proportion of nursing students. The shift to online mode aimed to offer an equivalent experience to both internal and external students using one, unified curriculum. One consequence was a strong emphasis on online groupwork for external students, in a context of learning about professional practice. There were 39 online groups (comprising 6-7 students each) to be managed by Fran and two colleagues. Three individuals were interviewed for this program: Fran and Margaret, lecturers, and Monica, a program coordinator.

The entities that made up the new sociotechnical assemblage of online teaching for $C P$ included: the unit $C P$, the 700 enrolled students, the unit coordinator, and a unit team of three colleagues as tutors, the online group work and assessment, the LMS, institutional policies, IT support, Faculty administration. The assemblage also extended outside the immediate learning setting, to include links to health practice, such as requirements and competencies for accreditation set by health regulatory bodies.

The actor network approach focusses on the process of translation while assembling the unit's online teaching. A dilemma gradually emerged: how does Fran negotiate a shift from face to face teaching of health practice to a context of mass online teaching. The process of translation is presented in Table 4.

Problematisation: Fran's initial task was connecting and coordinating separate processes of the institution to the new environment, that is, constituting the unruly assemblage of entities that made up online teaching. During the first iteration of $C P$, these processes converged on online assessment, and a series of actors made insistent demands on Fran. These demands were administrative, managerial, technological and pedagogical, and they became manifest in an institutional regime of on screen marking. A new institutional policy required a two week cycle of marking and return 
Table 4: The shift to online teaching of a large class

\begin{tabular}{|c|c|c|c|}
\hline Problematisation & Interessement & Enrolment & Mobilisation \\
\hline $\begin{array}{l}\text { How is coordination } \\
\text { and teaching of a large } \\
\text { class unit shifted } \\
\text { online? How does } \\
\text { Fran shift her } \\
\text { discipline based conc- } \\
\text { eptions of learning } \\
\text { online to the LMS? }\end{array}$ & $\begin{array}{l}\text { Connecting actors in } \\
\text { the new assemblage: } \\
\text { coordinating the LMS, } \\
\text { online marking } \\
\text { system, tutors, } \\
\text { managing exceptions } \\
\text { outside the system. }\end{array}$ & $\begin{array}{l}\text { Learning and } \\
\text { assessment is } \\
\text { translated on the LMS. } \\
\text { However, the } \\
\text { conditions are narrow } \\
\text { and not all students } \\
\text { are accepted. }\end{array}$ & $\begin{array}{l}\text { The new online } \\
\text { teaching assemblage } \\
\text { was mobilised despite } \\
\text { weak links, including } \\
\text { those with models of } \\
\text { professional practice. }\end{array}$ \\
\hline
\end{tabular}

of student assignments, and Faculty restrictions on printing required marking to be conducted on screen. Fran compared marking as a manual process with the on screen process, where "course" refers to one unit of study:

Fran: I actually find that, the actual marking is good. It's the front-end work, and the back-end work ... you have got to download your documents, put it in a zip file, transfer it to from the zip file to a marking file, then you've got to import your criteria sheet, and that actually adds about four hours, you know for my last, because I'm doing 100 - and this time, and I was marking 375 Word documents online!

John: In one course?

Fran: In one course!

Fran had found the marking process on screen and on paper as equally demanding, however the "front end work and the back end work" of on screen marking were onerous. Not factored into the online marking process was the management of extensions and manual assignments (from students with Internet access problems). This meant accommodating those for whom the system did not work:

you're moving between marking systems, okay you are marking manually, you're marking online, you are handling documents ...

Fran noted that the agency of her practice has now shifted, "I am constrained to actually sitting in front of this computer", narrowing the choice of time and place for marking. The initial problematisation, constituting a new agency for unit coordination, had shifted from Fran as unit coordinator to a shared agency of coordination with the LMS. In addition, Fran concurrently managed the earlier manual process for those students who did not meet the requirements of the new online system, the exceptions. Coordination was now a tightly coupled hybrid of person and database.

Interessement: The engagement of key actors in building an assemblage for teaching online required adapting prior arrangements and coordinating a series of new operations, that is, operations that shifted teaching and assessment from face to face settings to online ones. One outcome was increased workload, as Fran's colleague Margaret puts it, "the word used around here is 'relentless'".

A consequence of this translation of teaching onto the LMS was the displacement and alignment of learning activities to the text based mode of electronic communication. Fran expressed concern with the reliance on online communication in a professional practice unit, citing a "humanistic model" for health professionals, which required a hands on approach, using technology as "an adjunct". For example, teaching the "subtle cues" involved in visual assessment of patients is best done in a face to face 
setting. Fran raised the question of how students can be prepared for clinical practice online, if "part of how they develop those skills is modelling on our behaviour".

Enrolment: With online discussion as the primary mode of interaction with students in $C P$, the nature of interaction for teaching and learning changed. Fran was concerned that text based online communication "has a potential to depersonalise communication and is open to misinterpretation". With such a large cohort, "personal interaction with a group of students of about 700 is pretty difficult", it was those students who were not coping who required the most attention:

generally the students that you interact with most are most of the students who have major problems. And you're either academically or personally counselling them or educationally counselling them. And using an electronic means (Fran).

Fran identified online communication as a shift from pedagogy towards counselling. In particular managing groupwork communication breakdowns by email and telephone was "very protracted" and time consuming. Consequently, she questioned how learning could occur in this unit.

Mobilisation: The conditions for standardised mass learning online occur when the administrative and technological actors are centralised, formalised and standardised (Cornford \& Pollock, 2003, p. 76), and the processes made seamless, that is, stabilised or blackboxed. In Fran's unit and degree program, online teaching was assembled and standardisation achieved, although with great effort. There were two implications for Fran and her colleagues: first, what was made non-standard were the exceptions, mainly students who did not have reliable online access. Fran estimated up to 30\% of students had difficulties with online technology. These exceptions, as enrolled students, were still part of the assemblage of online teaching, but invisible to the standardised process of onscreen marking. Moreover the effort of accommodating exceptions excluded by the standardised LMS was delegated to teaching staff, who picked up the now expanded hidden work of bringing the student exceptions into the assemblage. Second, the pedagogical approach for teaching clinical practice was now delegated to the mode of online asynchronous, text based communication, and for Fran and her colleagues, this mode did not align with their discipline based experience of hands on teaching of clinical practice.

While no breakdown occurred with the newly constituted online teaching unit in a technical or organisational sense - the unit $C P$ continued - the conditions for participation were so narrowly defined that people were continually at risk of falling out of the assemblage: students who could not be translated into standardised performance, and teaching staff to whom the link between teaching and practice was weakened or marginalised.

\section{Discussion}

Two innovations were described, both producing "disruptive" change in their own contexts, one a bottom up initiative originating from a individual teaching academic and implemented in several units, the other, top down, was part of program wide organisational change. In each case breakdowns interrupted or distorted the innovation. To analyse how the resistances and breakdowns emerged using the relational perspective described above, it is necessary to review each sociotechnical 
assemblage and include some "action at a distance" which impacted on the local setting.

In the relational perspective using actor network analysis, the entities involved may be technical, social or discursive, but there is no privileging of one category over another, nor are there barriers in describing relations between them. The key to the success of an innovation is alignment of all actors via the process of translation, in which decisions, selections and sequences of actions, are displaced and delegated. Actor network theory explores the process of "orchestration, ordering and resistance" (Law, 1992), until the assemblage is stabilised, or blackboxed, and itself becomes an actor. Once stabilised, the assemblage acts and becomes mobile, and in a sociotechnical environment like online teaching in a university, this occurs not just through a production process but also via a discursive process. An institutional LMS may achieve alignment with the institution and become a stabilised black box for online teaching. This is accomplished when online teaching is translated both onto the LMS technology, and summarised by the term "LMS". Finally, each becomes mobile as a dominant technology and discourse throughout the institution.

In order to account for the breakdown of the wiki assemblage, it is necessary to accommodate actors that have effects from a distance, both spatially and temporally. The wiki assemblage comprised the entities who enacted learning in Jack's unit CS, ranging from: the people (the coordinator, 510 students, 13 tutors, Faculty people), the technologies (the wiki itself, the university student database and infrastructure), and institutional policies. There were two prior actors which shaped the project. One emerged from Jack's initial decision to deploy the wiki: Jack identified constructivist learning concepts as a resource for his wiki, and he found a mismatch between the latent pedagogy of the LMS and his concept of learning. Hence constructivist learning, an expression that summarises a discourse with wide application in higher education, is an immutable mobile, and an initial actor in the wiki assemblage. The second actor was the "philosophy of open source", which Jack aligned with constructivist learning. Hence open source software also emerged as a resource for Jack's collaborative online teaching approach, and Jack used this to entice (interessement) students into his open assessment strategy.

Two further entities also performed actions at a distance, in addition to the two above. The third was "student evaluations", an actor yet to manifest, which nevertheless "acted" to resist further iterations of the unit of study CS. Ultimately CS became contingent on the student evaluations, as ties with other entities weakened, and student numbers increased, leaving Jack vulnerable to negative evaluations of the wiki. The fourth distant actor was the incumbent institutional LMS which, though not used in CS, was nevertheless present. The resident LMS had strong ties with the information technology unit and institutional policy, setting a standard environment for online teaching, and claimed the pivotal status of "obligatory passage point" for online teaching. The wiki, in contrast, had weak ties with both these institutional players, and its presence marked its status as non-standard to the university, and hence to the students. Jack's plea, “We all agree on the road rules, but we don't have to all drive Holden Barinas" was a reference to standardising effect, the hidden online pedagogy, of the LMS. After two iterations of CS, the existing alignment between the LMS, university infrastructure and policies weakened those ties between the wiki and the university, despite Jack's efforts and increased workload. The distant actors, student evaluations and the LMS, had strong ties with the university, and built 
resistances and eventual breakdown to the wiki assemblage. Contacted nine months later, Jack stated, "We're back to driving Barinas!"

In the top down innovation of Fran's unit, $C P$, she described the effect on her practice of the shift to the unified online curriculum in two ways: first, as unit coordinator, she was trying to integrate administrative processes, institutional needs and learning technologies into a functioning online teaching and learning environment for over 700 students. Second, as lecturer and coordinator, she described a tension created by the new teaching arrangements, with the substitution of online groupwork for hands on modelling of clinical practice. This did not fit her conception of $C P$ as "a human based profession", and queried how this could be reconciled with such an strong emphasis on technology based learning.

Again, discourses of learning became a distant actor in this assemblage of online teaching: in Fran's case, her prior conceptions of teaching emerged from health care practice and valued teaching by modelling clinical behaviour. First, the translation of the discourse and hands on practice of "humanistic" care onto mass online groupwork was neither tenable nor workable for Fran and some colleagues. Second, the LMS produced a new category: that of the exception, the non-standard student, for whom continual work was required to accommodate and keep them in the assemblage, displaced onto increased workload. (An example of the production of a new category by online technology is given by Land (2004) in the example of the "lurker" which is constituted by online environments). The breakdown, for Fran and Margaret, commenced at the outset, where the inclusion of online groupwork for assessment in $C P$ was not negotiated with Fran's conceptions of teaching health care practice. The point of breakdown, for Fran, was the misalignment between online teaching and her discipline. Again, the assumed neutrality of online pedagogy using the LMS was translated as an unproblematic shift from face to face communication to a distance mode.

First, the sociotechnical assemblage of the unit $C P$ encompassed the hands on practices of the health care industry, which were adapted to the new online curriculum, and for Fran and some of her colleagues this adaptation did not align with the form of learning at a distance which was designed into their online teaching.

\section{Conclusion}

Two cases of innovation were analysed to explore instances of a pattern of breakdown and shortcomings in online teaching and learning in higher education. The analysis illustrated the contention of this paper that the separation of the social and technical factors which shape an innovation - pedagogical, technological, organisational and discursive - will increase the likelihood of breakdowns. The analysis is based on a relational perspective drawn from actor network theory and discourse analysis, and in summary, this view suggests that an innovation will be successful if all the actors, that is, entities which perform actions, are able to form associations based on strong ties, and are brought to alignment and mobilised into a sociotechnical assemblage. In both cases, action at a distance occurred via discursive "immutable mobiles", with shaping effects on online teaching in the local case setting.

One question arising from the two cases is how innovation, that is, transformative change, can occur in the context of mass teaching and learning, that is, the tension 
between innovation and standardised approaches to online teaching. At issue is the tendency of blackboxes, such as an LMS, to be totalising both as technologies and as discourses, and to set an institutional "standard" approach to online teaching which may be the antithesis of innovation. As such they will contest and resist alternative pedagogical models brought to the assemblage. Technologies and discourses need to be recognised as part of the assemblage of online teaching, but not stand for online teaching. These entities that arrive at a sociotechnical assemblage of online teaching must not be assumed, but an effort made to identify the black boxes, open them and then negotiate them.

\section{References}

Alexander, S. (2006). Dissemination of innovations: A case study. In Who's learning? Whose technology? Proceedings ascilite Sydney 2006.

http: / / www.ascilite.org.au/conferences / sydney06/proceeding/pdf_papers/p182.pdf

Alvesson, M. \& Sveningsson, S. (2008). Changing organizational culture: Cultural change work in progress. London; New York, NY: Routledge.

Arnold, M. (2007). The concept of community and the character of networks. The Journal of Community Informatics, 3(2).

Bacsich, P. (2005). Lessons to be learned from the failure of the UK e-University. In Breaking down boundaries: 17th Biennial Conference of the Open and Distance Learning Association of Australia. http: / / www.unisa.edu.au/odlaaconference/PDFs/32\%20odlaa2005\%20-\%20bacsich.pdf [viewed 26 July 2008, verified 16 Jan 2009]

Bigum, C. \& Rowan, L. (2004). Flexible learning in teacher education: Myths, muddles and models. Asia Pacific Journal of Teacher Education, 32(3), 213-226.

Callon, M. (1986). Some elements in a sociology of translation: Domestication of the scallops and fishermen of St. Brieuc Bay. In J. Law (Ed.), Power, action and belief: A new sociology of knowledge? (pp. 196-233). London: Routledge

Charette, R. (2005). Why software fails. IEEE Spectrum, September. [verified 16 Jan 2009\} http: / / www.spectrum.ieee.org/ sep05/1685

Conole, G., de Laat, M., Dillon, T. \& Darby, J. (2008). 'Disruptive technologies', 'pedagogical innovation': What's new? Findings from an in-depth study of students' use and perception of technology. Computers \& Education, 50, 511-524.

Conole, G. (2007). Distilling lessons from across different types of elearning interventions. In WWWrong: What went wrong? What went right? Exchanging experiences in technology enhanced learning, 17-18 September, Crete, Greece.

Cooren, F., Matte, F., Taylor, J. \& Vasquez, C. (2007). A humanitarian organization in action: Organizational discourse as an immutable mobile. Discourse E Communication, 1(2), 153-190.

Cornford, J. \& Pollock, N. (2003). Putting the university online: Information, technology and organizational change. Buckingham, UK: Open University Press.

Couldry, N. (2008). Form and power in an age of continuous spectacle. In D. Hesmondhalgh \& J. Toynbee (Eds.), Media and social theory. Routledge.

Downes, S. (2006). Learning networks and connective knowledge. Instructional Technology Forum. [verified 16 Jan 2009] http:/ / it.coe.uga.edu/itforum/paper92/DownesPaper92.pdf 
Edwards, R., Nicoll, K., Solomon, N. \& Usher, R. (2004). Rhetoric and educational discourse: Persuasive texts? London: RoutledgeFalmer.

Fox, S. (2005). An actor network critique of community in higher education: implications for networked learning. Studies in Higher Education, 30(1), 95-110.

Goodyear, P. \& Ellis, R. (2008). University students' approaches to learning: Rethinking the place of technology. Distance Education, 29(2), 141-152.

Hannon, J. (2008). Doing staff development: Practices, dilemmas and technologies. Australasian Journal of Educational Technology, 24(1), 15-29. http:/ / www.ascilite.org.au/ajet/ajet24/hannon.html

Ihde, D. (2002). Bodies in technology. Minneapolis: University of Minnesota Press.

Land, R. (2004). Issues of embodiment and risk in online learning. In Beyond the comfort zone: Proceedings ASCILITE Perth 2004. http:/ / www.ascilite.org.au/ conferences/perth04/procs/land.html

Latour, B. (1999a). On recalling ANT. In J. Law \& J. Hassard (Eds.), Actor network theory and after. Boston, Mass: Blackwell Publishers.

Latour, B. (1999b). Pandora's hope: Essays on the reality of science studies. Cambridge and London: Harvard University Press.

Latour, B. (1992). Where are the missing masses? The sociology of a few mundane artifacts. In W. Bijker \& J. Law (Eds.), Shaping technology/building society: Studies in sociotechnical change. Cambridge, Mass: MIT Press, pp. 225-258.

Latour, B. (1987). Science in action. Cambridge, MA: Harvard University Press.

Latour, B. (1986). The powers of association. In J. Law (Ed.), Power, action and belief: A new sociology of knowledge? London: Routledge, pp. 264-280.

Law, J. (2000). Networks, relations, cyborgs: On the social study of technology. http:/ / www.lancs.ac.uk/fass/sociology/research/resalph.htm [viewed 26 July, 2008].

Law, J. (1999a). Objects, spaces, others. http:/ / www.lancs.ac.uk/fass/sociology/ papers/lawobjects-spaces-others.pdf [viewed 26 July, 2008].

Law, J. (1999b). After ANT: Complexity, naming and typology. In J. Law \& J. Hassard (Eds.), Actor network theory and after. Oxford: Blackwell, pp. 1-14.

Law, J. (1992). Notes on the theory of the actor network: Ordering, strategy and heterogeneity. Systems Practice, 5, 379-393.

Lewis, T., Marginson, S. \& Snyder, I. (2005). The network university? Technology, culture and organisational complexity in contemporary higher education. Higher Education Quarterly, 59(1), 56-75.

McLoughlin, C. \& Lee, M. (2007). Future learning landscapes: Transforming pedagogy through social software. Innovate, 4(5). http: / / innovateonline.info / ?view=article\&id=539

McMullin, B. (2005). Putting the learning back into learning technology. In G. O'Neill, S. Moore \& B. McMullin (Eds.), Emerging issues in the practice of university learning and teaching. Dublin: AISHE.

Oblinger, D. G. \& Oblinger, J. L. (2005). Educating the net generation. An Educause e-book publication. http:/ / www.educause.edu/ir/library/pdf/pub7101.pdf [viewed 26 July 2008] 
Patton, M. Q. (2002). Qualitative research and evaluation methods (3rd ed.). Thousand Oaks, Calif.: Sage Publications.

Potter, J. (2000). Representing reality: Discourse, rhetoric and social construction (2nd ed.). London: Sage.

Potter, J. \& Wetherell, M. (1987). Discourse and social psychology: Beyond attitudes and behaviour. London, Newbury Park, CA: Sage Publications.

Roberts, G. (2004). The new covert curriculum: A critical actor-network approach to learning technology policy. In Proceedings of the fourth international conference on networked learning, Lancaster University and the University of Sheffield. [verified 16 Jan 2009]

http:/ / www.networkedlearningconference.org.uk/past/nlc2004/proceedings/individual_ papers/roberts.htm

Romiszowski, A. (2004). How's the e-learning baby? Factors leading to success or failure of an educational technology innovation. Educational Technology, 44(1), 5-27.

Warzynski, C. (2006). An actor-network approach to leading technological change: Implementing a new technology at a prominent U. S. research university. In A. M. Poorthuis (Ed.), The network approach: Building organisations and society. Amsterdam: Van Gorcum.

Weisenberg, F. \& Stacey, E. (2005). Reflections on teaching and learning online: Quality program design, delivery and support issues from a cross-global perspective. Distance Education, 26(3), 385-404.

Zemsky, R. \& Massy, W. (2004). Thwarted innovation: What happened to e-learning and why. A final report for the Weatherstation Project of the Learning Alliance at the University of Pennsylvania in cooperation with the Thomson Corporation. [viewed 26 July 2008] http:/ / www.irhe.upenn.edu/Docs/Jun2004/ThwartedInnovation.pdf

This article received an Outstanding Paper Award at ascilite Melbourne 2008 Conference, gaining the additional recognition of publication of a revised version with minor changes in AJET. The reference for the Conference version is:

Hannon, J. (2008). Breaking down online teaching: Innovation and resistance. In Hello! Where are you in the landscape of educational technology? Proceedings ascilite Melbourne 2008. http:/ / www.ascilite.org.au/conferences/melbourne08/procs/hannon.pdf

John Hannon, Lecturer, Online and Flexible Learning, Curriculum, Teaching and Learning Centre, La Trobe University. Email: j.hannon@latrobe.edu.au Web: http:/ / www.latrobe.edu.au/ctlc/staff/hannon.html 